\title{
Transformational Leadership and Its Relation to Organizational Commitment among Employees in Public Institutions: a Case Study of Shaqra University, Saudi Arabia
}

\section{RASHED GHAZI AL-HUWAIL AL-OTAIBI}

Department of Business Administration,

College of Sciences and Humanities, Shaqra University, Saudi Arabia.

Email: ralotaibi@su.edu.sa

\begin{abstract}
The study seeks to identify the degree of practicing the transformational leadership at Shaqra University from the view of its employees, the degree of organizational commitment among the employees, and also the relationship between practicing transformational leadership and organizational commitment among the employees to detect the differences in both of transformational leadership and organizational commitment among the employees relative to sex, educational qualification or experience. A stratified random sample $(N=231)$ of employees of Shaqra University was interviewed. The empirical evidence shows that the degree of practicing the transformational leadership from the view of its employees as well as the degree of organizational commitment among the employees is found to be high. The evidence also indicates that there is a statistically significant relationship between practicing transformational leadership and organizational commitment among the employees. However, no statistically significant differences in both of transformational leadership and organizational commitment among the employees were detected. This result is due to the heterogeneous related to socio-demographic characteristics like sex, educational qualification, or experience years. In light of the foregoing outcomes, some recommendations are formulated.
\end{abstract}

Keywords: Transformational Leadership, Organizational Commitment, Employees, Shaqra University.

\section{Introduction}

In terms of leadership patterns that have been produced by scientific and technical progress, transformational leadership is recognized by the ability to face challenges by influencing the behavior of workers, developing their creative capabilities, encouraging them to solve problems facing them or facing their institutions in creative ways, expanding their interest, deepening their level of awareness, and accepting the vision of the institution and its objectives (Al-Thuwaini, 2014).

However, leadership represents one of the important topics that has received the attention of many researchers, as the progress of society and the development of its institutions depend mainly on the leadership patterns followed, and the leadership of the institutions possessing innovative capabilities and creative talents, in addition to providing an appropriate climate to increase the productivity of workers. The importance of transformational leadership is due to the fact that it works to expand the interests of employees, deepen their level of awareness and acceptance of the institution's vision and mission, and provide continuous care to every member of the organization, develop their capabilities, instill in them confidence, and involve them in leadership, achieving compatibility between their objectives and the objectives of the institution (Conger, 2002; Sadeghi \& Pihie, 2012). It is play a catalyst for high 
performance among workers, as it gives them strength, freedom and information to participate in decisionmaking, and makes them feel that they represent an essential component of the institution, as well as its importance in providing an encouraging work environment, which leads to keeping pace with contemporary requirements and developments (Al-Otaibi, 215, 2016). The transformative leader is the one who can make positive changes in the organization, by having a clear vision and a strong belief in the desired objectives, taking into account individual considerations, interest in searching for new ideas and appropriate means to accomplish the work, and stimulate the motivation and enthusiasm of the workers (Abu Al-Nasser, 2009).

The transformational leadership style is characterized by a high ability to face modern challenges and developments, and open the way for workers to innovate more, by opening the channels of development and renewal, to keep pace with the surrounding changes and rapid transformations (Abdul Rahman, 2014). Al-Khawaldeh and Jaradat (2011) explain that the application of transformational leadership in universities requires the availability of a set of methods that assist leaders in performing their duties as required, such as: the continuous development of workers, the activation of communication and the unification of shared visions between them, the provision of feedback and the continuous encouragement of change and continuous development. Some researchers (e.g., Allen \& Meyer, 1997; Klein, 2012; Becker \& Meyer, 2012) explain that organizational commitment is one of the main objectives that all institutions seek to achieve because of its impact on the continuity of individuals and the stability of work. The organizational commitment in contemporary administrative thought reflects the extent of sincerity and integration shown by the individual towards his work, and its reflection on his acceptance of the institutional objectives that he works with and his continuous dedication to achieving them.

Organizational commitment plays a key role in achieving organizational objectives, enhancing creativity, achieving institutional stability, and increasing trust between management and workers, as it contributes to developing the institution's capabilities to survive and continuous growth, therefore, the study of organizational commitment, and the factors associated with it, occupy an important position in the field of management as general, and in the field of business administration in particular (Taner, Turhan \& Helvaci, 2015). In addition, organizational commitment is the emotional and emotional bond between the individual and the institution, and increases the individual's desire for social interaction in order to provide them with vitality and activity and give them loyalty, and workers with high levels of organizational commitment are the most remaining in institutions, because there is a strong motivation for their survival in them (Darwish, 2008).

Despite the importance of organizational commitment in achieving the objectives of the various institutions, there are some ignored factors that may negatively affect the level of organizational commitment of workers in these institutions, and among these factors is the leadership style followed in the institution Through the researcher's extrapolation of previous studies, it became clear the scarcity of studies that touched on the relationship between transformational leadership and organizational commitment among workers in Saudi universities, especially since most of the studies that addressed transformational leadership in Saudi society have been applied at the school level, which motivated the researcher to conduct the current research. Therefore, the present study seeks to identify the relationship between the practice of leadership and transformational leadership and organizational commitment among employees at Shaqra University.

Specifically, this research attempts to answer the following questions:

1. What is the degree of administrative leadership practice of transformational leadership in Shaqra University from the viewpoint of its employees?

2. What is the degree of organizational commitment for workers at Shaqra University?

3. What is the relationship between the practice of administrative leaders of transformational leadership and the organizational commitment of workers at Shaqra University? 
4. Are there statistically significant differences in the degree of managerial leadership practicing transformational leadership at Shaqra University from the viewpoint of its employees due to gender changes, educational qualifications or experience?

5. Are there statistically significant differences in the degree of organizational commitment of employees at Shaqra University attribute to sex, educational qualifications or years of experience?

\section{Review of Literature}

\section{Transformational Leadership}

The concept of transformational leadership emerged by Bums (1978), where he stressed the need for the leader of the institution to take care of the psychological aspect of workers, in order to mobilize energies to achieve the objectives of the institution, by discovering the underlying and apparent motives of workers, and influencing their behavior to meet the challenges that the organization may face, from during building commitment to the objectives and strategies of the institution.

It is well known that transformational leadership is one of the most important leadership styles that different institutions need (Al-Amiri, 2002; Conger, 2002; Burns, 2004; Radwan, 2012), and many studies (e.g., Bayram and Ding, 2015; Ortega \& Freites, 2019) have categorized the efforts of transformational leaders in contemporary institutions as two main aspects: the first is the organizational side, which includes efforts to rebuild and restructure the institutional organization, and to bring about changes in the formal construction of the institution, which includes a direct impact on improvement and improvement in the organization's performance. The second is the cultural and emotional aspect, which includes efforts aimed at rebuilding the cultural landscape in the institution, in order to bring about changes in motivation, skills, and organizational relationships, which leads to the promotion of new methods and means of collaborative teamwork within the institution.

The subject of transformational leadership has received considerable attention over the last few years. For example, Khalaf (2010) studies the relationship between transformational leadership and administrative creativity that led the heads of academic departments at the Gaza Islamic University. The results show a high degree of transformational leadership practice, and the presence of a correlative relationship between transformational leadership and administrative creativity. Sadeghi \& Pihie (2012) examined the role of transformational leadership in the success of academic institutions in Malaysia. The results show that there is a high degree of transformational leadership in the success of academic institutions. Al-Thuwaini (2014) investigates the degree of the practice of heads of academic departments at King Saud University for transformational leadership from the viewpoint of faculty members. The results indicate that the degree of the practice of the heads of the academic departments of transformational leadership is high. The results further indicate statistically significant differences in the sample to the degree of transformational leadership practice attribute to the benefit of males and no statistically significant differences attributed to the scientific rank. Tahir, Tina and Daud (2014) explore the relationship between transformational leadership and academic commitment among faculty members in Malaysian universities, and find a positive relationship between transformational leadership and academic commitment in the study sample.

Al-Rashidi (2017) investigates the relationship between transformational leadership and organizational creativity among deans and heads of departments in public and private universities in Riyadh. The study sample consisted of 147 individuals from academic leaders. The results show that the degree of transformational leadership practice came in a high degree, and that there is a positive correlation between transformational leadership and organizational creativity. Al-Tuwaijri study (2017) studies the relationship between transformational leadership and decision-making effectiveness among heads of educational supervision departments in Buraidah for a sample of 100 educational supervisors. The results show a positive correlation between transformational leadership and decision-making effectiveness. However, the results indicate no statistically significant differences in the degree of transformational leadership practice 
attributable to gender, educational qualification or years of service. Somali and Mitwalli (2018) analyze the relationship between transformational leadership and the empowerment and creativity of administrative staff at King Abdulaziz University for 333 administrative employees. The results show a positive association between transformational leadership and employee empowerment, and also a positive correlation between transformational leadership and employee creativity. Al-Saleh (2019) analyzes the degree of academic leaders in Saudi universities practicing transformational leadership, and the study sample consists of 535 faculty members. The results show that there is an average degree for the academic leaders in Saudi universities to practice transformational leadership. However, the results suggest that there is no statistically significant differences to the degree of the academic leader's practice of transformational leadership attributed gender, job or years of experience.

\section{Organizational Commitment}

Several studies (e.g., Nwadei, 2004; Bien \& Hunt, 2006; Brown \& Amstrong 2011, Schermerhorn et al., 2011; Abu Ashkar \& Jubran, 2019) argued that organizational commitment is a major part of organizational behavior that organizations try to maintain and seek to develop among workers. The perception of the concept of organizational commitment differs according to the direction of that commitment. The organizational commitment represents an important element in linking the institution and its employees, especially in times when the organization cannot provide incentives to push workers towards achieving high levels of performance. It is also a strong indicator of the continuity and survival of workers in their workplaces, and therefore an important factor in predicting the effectiveness of the institution (Allen \& Meyer, 1997; Klein, Battah, 2006; Becker \& Meyer, 2012; Meyer, 2016). However, Tiwari (2009) and Wesson, Jeffery and Colquit (2016) explain that organizational commitment results from the interaction of three main elements: (i) conformity, which refers to the adoption of the objectives and values of the institution, as the objectives and value of the individual worker himself; (ii) exhaustion, which refers to the individual being immersed in carrying out the activities of the institution, (iii) loyalty, which refers to the individual feeling a strong emotional attachment to the institution.

The issue of organizational commitment has received considerable attention during the past decades. For instance, Qasim (2011) examines the impact of the original leadership as an intermediate variable on the relationship between the quality of work life and organizational commitment for a sample of 400 individuals from the medical units of Egyptian Mansoura University. The evidence shows that the level of organizational commitment is affected by their different perception of the dimensions of the quality of career life. The results also show that the original leadership behaviors affect as a mediating variable the strength of the positive relationship between the members of the sample's awareness of the quality of career life and their sense of organizational commitment. Bailey (2012) analyzes the level of organizational commitment of employees in public and private universities in Turkey. The results show that a high level of organizational commitment among the individuals. Moreover, a statistically significant difference in the level of organizational commitment among workers in public and private universities for the benefit of workers in government universities is detected.

Al-Nuwayqa (2013) investigates the effect of organizational confidence in achieving organizational commitment among 120 workers at Taif University. The empirical evidence shows a positive relationship between organizational trust and organizational commitment, and that there is a significant statistical effect of organizational confidence on organizational commitment. Moreover, Essa (2016) analyzes the impact of the application of spiritual leadership on the organizational commitment of employees at Taif University for a sample of 136 female administrative employees working in the supporting departments. The evidence shows a positive statistical effect of spiritual leadership on the organizational commitment. The study of Safar (2017) analyzes the relationship between job empowerment and organizational loyalty among 223 female employees of Umm Al-Qura University. The results show a positive relationship between functional empowerment and organizational loyalty. Al-Maaini (2018) examines the role of job satisfaction as an intermediate factor in the impact of organizational justice on the organizational commitment of 314 
workers in Jordanian private universities. The results show a high level of organizational commitment among the workers, and that there is a positive effect of a statistical function of organizational justice on the organizational commitment. However, the results indicate no statistically significant effect of job satisfaction in improving the impact of organizational justice on organizational commitment.

\section{Methodology}

\section{The Sample}

The descriptive approach is used because it fits with the nature of the current research and its objectives, with the aim of identifying the relationship between transformational leadership and organizational commitment among employees at Shaqra University. A stratified random sample $(\mathrm{N}=245)$ of employees was interviewed in their workplace between October and December 2019. Out of the 245 individuals from the administrative staff, 231 were complete and approved the questionnaires and all participants have reported on their socio-demographic characteristics according to gender, educational qualifications and years of experience. Table 1 summarizes the distribution of the study sample.

Table 1. Distribution of Employees by Gender, Educational Qualifications and Years of Experience

\begin{tabular}{|c|c|c|c|}
\hline Variable & Variable category & Number & Percentage) \\
\hline \multirow{3}{*}{ Gender } & Male & 140 & $60.61 \%$ \\
\cline { 2 - 4 } & Female & 91 & $39.39 \%$ \\
\cline { 2 - 4 } & Total & 231 & $100 \%$ \\
\hline \multirow{3}{*}{ Qualification } & Undergraduate qualification & 68 & $29.44 \%$ \\
\cline { 2 - 4 } & college degree & 139 & $60.17 \%$ \\
\cline { 2 - 4 } & Postgraduate & 24 & $10.39 \%$ \\
\cline { 2 - 4 } & Total & 231 & $100 \%$ \\
\hline \multirow{3}{*}{$\begin{array}{c}\text { Years of } \\
\text { Experience }\end{array}$} & Less than 5 years & 42 & $18.18 \%$ \\
\cline { 2 - 4 } & From 5 to less than 10 years & 128 & $55.41 \%$ \\
\cline { 2 - 4 } & 10 years and over & 231 & $100 \%$ \\
\hline
\end{tabular}

It is clear from Table 1 that the number of males in the research sample reached (140) individuals with a percentage $(60.61 \%)$ of the total sample, while the number of females (91) individuals reached (39. 39\%) of the total sample. As for the academic qualification, the number of those obtaining a qualification less than the university reached (68) individuals with a percentage (29. 44\%) of the total sample, while the number of those with a university qualification reached (139) individuals with a percentage $(60.17 \%)$ of the total sample, the number of graduate students (24) individuals (10.39\%) of the total sample. As for years of experience, the number of individuals with less than 5 years of experience has reached (42) individuals, at a rate of $(18.18 \%)$ of the total sample, while the number of individuals with experience of less than 5 years (128) individuals has reached (55. 41) \%) of the total sample, and the number of individuals with experience 10 years and over (61) individuals $(26.41 \%)$ of the total sample.

\section{The Questionnaire}

The questionnaire was used as a tool to collect data in the current study, due to its relevance to the research topic and to achieve its objectives and answer its questions. The questionnaire was built in light of the following steps:

- Determining the goal of the questionnaire: it is the identification of the relationship between transformational leadership and organizational commitment. 
- Defining the theme of the questionnaire: the questionnaire included two theme, namely: transformational leadership (and includes 30 paragraphs distributed in five areas: good example, inspirational motivation, intellectual stimulation, individual considerations, and empowerment), and organizational commitment (and includes 22 paragraphs distributed in three areas, namely: Loyalty to the university, responsibility towards the university, and the desire to continue working at the university).

- Drafting paragraphs of the questionnaire: after defining the theme of the questionnaire, the paragraphs for each axis were formulated, in the light of the theoretical literature of the current research variables, and in the light of previous studies related to the subject of the research, and in light of reviewing some of the questionnaires used in these previous studies, and using them in formulating Resolution paragraphs used in the current research.

- Grading response alternatives and defining a standard for the degree of approval of the questionnaire paragraphs: the Likert method was used where the individual responds to each paragraph by determining the degree of his agreement to each of them by choosing one of the alternatives (agree - to some extent - not agree), and has each of these alternatives is given a weighted weight, where (3) scores are calculated in the case of choosing (approved), two steps are calculated in the case of selection (to some extent, one degree is calculated in the case of choosing (not approved).The research sample for each paragraph of the questionnaire and for each of its theme, a range of scores for each paragraph was calculated, where the extent of the questionnaire answer $=$ (highest grade - lowest grade) $\mid$ number of categories - (3-1) / 3- (0 .67), which is the category length, so if the arithmetic mean of the paragraph ranges from (2.33) to (3) then the degree The approval of this paragraph by the members of the research sample is high, and if the arithmetic mean of the paragraph ranges between (1. 67) to less than (2.33) then the degree of approval of this phrase by the members of the research sample is medium, and if the arithmetic mean of the paragraph ranges between (1) to less than (1.67), the degree of approval of this paragraph by members of the research sample is low.

- Formulating the instructions for the questionnaire: The questionnaire instructions were formulated in order to inform the members of the research sample of the purpose of this questionnaire, its components, and the way to respond to it, while emphasizing that the responses of the individuals of the sample to the questionnaire will be used for the purpose of scientific research only.

- Validity and reliability of the questionnaire: the validity of the questionnaire was verified in two ways:

- The validity of the arbitrators: after preparing the initial image of the questionnaire, it was presented to ten arbitrators who specialize in the subject of the research, and they were asked to kindly arbitrate the questionnaire and express their opinions regarding both: the extent of clarity of the paragraphs and the soundness of formulating them, and determining the extent of belonging to the paragraphs of the axis that it measures, and the appropriate extent to formulate alternatives to response . A percentage of approval $(80 \%)$ or more of the opinions of the arbitrators has adopted a criterion for retaining the paragraph, taking into account the amendments and observations made by the arbitrators about amending the wording of some paragraphs.

- The validity of the internal consistency: the validity of the internal consistency of the questionnaire was verified by applying it to a prospective sample of (45) individuals from Shaqra University and from outside the core research sample. The values of the Pearson linear correlation coefficients between the degree of each paragraph and the degree of the axis to which the paragraph belongs The overall degree of the questionnaire, and the values of the Pearson linear correlation coefficients were calculated between the degree of each axis and the overall degree of the questionnaire. The values of the correlation coefficients ranged between (0.69) to (0.92), all of which are statistically significant values at the level of $(0.01)$, which Refers to the resolution of the questionnaire with an appropriate degree of internal consistency.

- Stability of the resolution: the stability of the questionnaire was verified in two ways, namely; Cronbach's $\alpha$ method: the researcher applied the questionnaire to the reconnaissance sample, who are (45) individuals from the University of Shaqra and from outside the basic research sample, then he calculated the value of the Cronbach's $\alpha$ coefficient in relation to the questionnaire as a whole and for each of its theme, and the results were as in the table next one: 
Table 2. Cronbach's $\alpha$ Coefficients for the Resolution as a Whole and for each of Its Themes

\begin{tabular}{|l|c|c|}
\hline \multicolumn{1}{|c|}{ Theme } & Cronbach's $\boldsymbol{\alpha}$ & Cronbach's $\boldsymbol{\alpha}$ \\
\hline The first theme: transformational leadership & 0.94 & 0.90 \\
\hline The first theme: organizational commitment & 0.91 & 0.87 \\
\hline The questionnaire as a whole & 0.93 & 0.92 \\
\hline
\end{tabular}

Overall, it is clear from Table 2 (column 1) that the value of the stability factor in the Cronbach's $\alpha$ method for the first axis (transformational leadership reached (94.9), and for the second axis (organizational commitment) amounted to (0.91), and for the questionnaire as a whole amounted to (93.9), all variables have high stability coefficients.

Table 2 (column 2) shows the method of application and re-application for 45 individuals after two weeks. It is clear from that the value of the stability factor in the way of application and re-application of the first axis of transformational leadership reached (0.90) and for the second axis (organizational commitment) amounted to (0.87), and the questionnaire as a whole amounted to $(0.92)$, inducing that all variables have high stability coefficients.

The questionnaire consisted in its final form of 52 paragraphs distributed on two theme, namely: transformational leadership (including 30 paragraphs distributed over five areas, namely: good role model, inspirational motivation, intellectual stimulation, individual considerations, and empowerment), and commitment organizational (including 22 paragraphs distributed in three areas, namely: loyalty to the university, responsibility towards the university, and the desire to continue working).

The statistical analysis was performed with SPSS 12.0 statistic software package. Pearson's linear correlation coefficient was used to test the validity of the internal consistency of the research tool, and to determine the relationship between transformational leadership and organizational commitment among the individuals in the research sample, in addition Cronbach's $\alpha$ coefficient was used to test the reliability of the research tool.

T-Test was also used to determine the differences in the degree of administrative leadership practice of transformational leadership at Shaqra University from the viewpoint of its employees and the differences in the degree of organizational commitment of workers at Shaqra University that may be attributed to the gender variable, and unidirectional variance analysis was employed (one way ANOVA) to determine the differences in the degree of management leadership practice of transformational leadership at Shaqra University from the viewpoint of its employees and the differences in Shaqra University which may be attributed to the variables of the educational qualification and the degree of organizational commitment of workers in years of experience.

\section{Empirical Results}

\section{Outcomes of Answering to "Question 1"}

The first question states, "What is the degree of administrative leadership exercising transformational leadership at Shaqra University from the viewpoint of its employees?" To answer this question, arithmetic averages and standard deviations were calculated. The responses of the research sample individuals on each of the fields of the first axis (transformational leadership) of the questionnaire and for each of the items of each field. The results are reported in Table 3. 
Table 3. Arithmetic Averages, Standard Deviations, Degree of Approval, and Ranking of Fields: First Axis (Transformational Leadership)

\begin{tabular}{|l|l|c|c|c|c|}
\hline No & \multicolumn{1}{|c|}{ Field } & $\begin{array}{c}\text { Arithmetic } \\
\text { Average }\end{array}$ & $\begin{array}{c}\text { Standard } \\
\text { Deviation }\end{array}$ & $\begin{array}{c}\text { Degree of } \\
\text { Approval }\end{array}$ & Ranking \\
\hline 1 & The first field: a good example & 2.57 & 0.35 & High & 1 \\
\hline 2 & $\begin{array}{l}\text { The second field: inspirational } \\
\text { stimulation }\end{array}$ & 2.42 & 0.29 & High & 3 \\
\hline 3 & The third field: intellectual arousal & 2.44 & 0.25 & High & 2 \\
\hline 4 & Fourth field: individual considerations & 2.26 & 0.31 & Medium & 5 \\
\hline 5 & Fifth Field: Empowerment & 2.36 & 0.28 & High & 4 \\
\hline $\begin{array}{l}\text { Overall average of first axis (transformational } \\
\text { driving) }\end{array}$ & 2.41 & 0.14 & High & \\
\hline
\end{tabular}

It is clear from Table 4 that the arithmetic mean of the total degree of the first axis (transformational leadership) reached (2.41) with a standard deviation (0.14) and with a high degree of approval, and that the arithmetic mean for the fields of this axis ranges from 2.26 to 2.57. The degree of approval ranges from medium to high. 4 Fields have a high degree of approval, while 1 field has an average degree of approval by the individuals in the research sample. The arrangement of these fields came according to the degree of approval by the members of the research sample as follows: good role models, then intellectual stimulation, then inspirational stimulation, then empowerment, then individual considerations. The following are the arithmetic averages and the standard deviations for the items for each of these fields:

- First field (good example)

- Second field (inspirational stimulation)

- $\quad$ Third field (intellectual stimulation)

- Fourth Field (individual considerations)

- Fifth Field (empowerment)

Table 4. Results of the First to Fifth Fields of the First Axis (Good Example, Inspirational Stimulus, Intellectual Stimulation, Individual Considerations, and Empowerment)

\begin{tabular}{|c|c|c|c|c|c|}
\hline No & Fields & $\begin{array}{c}\text { Arithmetic } \\
\text { Average }\end{array}$ & $\begin{array}{l}\text { Standard } \\
\text { Deviation }\end{array}$ & $\begin{array}{l}\text { Degree of } \\
\text { Approval }\end{array}$ & Ranking \\
\hline \multicolumn{6}{|c|}{ 1st field (good example) } \\
\hline 1 & $\begin{array}{l}\text { Commitment to the best values of } \\
\text { behavior }\end{array}$ & 2.68 & 0.56 & High & 1 \\
\hline 2 & Appreciate the workers' efforts & 2.55 & 0.64 & High & 3 \\
\hline 3 & Words agree with deeds & 2.48 & 0.67 & High & 4 \\
\hline 4 & Take responsibility for making decisions & 2.58 & 0.69 & High & 2 \\
\hline \multicolumn{2}{|r|}{$\begin{array}{l}\text { Overall average for the } 1 \mathrm{st} \text { field (good } \\
\text { example) }\end{array}$} & 2.57 & 0.35 & High & \\
\hline \multicolumn{6}{|c|}{ 2nd field (inspirational stimulation) } \\
\hline 5 & $\begin{array}{l}\text { The ability to deal with difficult } \\
\text { situations }\end{array}$ & 2.55 & 0.61 & High & 2 \\
\hline 6 & Encourage teamwork & 2.71 & 0.57 & High & 1 \\
\hline 7 & $\begin{array}{l}\text { Urging workers to achieve more work } \\
\text { achievement }\end{array}$ & 2.42 & 0.70 & High & 4 \\
\hline 8 & $\begin{array}{l}\text { Raising the spirit of challenge and } \\
\text { perseverance among workers }\end{array}$ & 2.14 & 0.69 & Medium & 6 \\
\hline
\end{tabular}




\begin{tabular}{|c|c|c|c|c|c|}
\hline 9 & $\begin{array}{l}\text { And help workers to solve problems in } \\
\text { creative ways }\end{array}$ & 2.23 & 0.71 & Medium & 5 \\
\hline 10 & $\begin{array}{l}\text { Encourage workers to discover creative } \\
\text { solutions to problems }\end{array}$ & 2.45 & 0.68 & High & 3 \\
\hline \multicolumn{2}{|r|}{$\begin{array}{l}\text { Overall average for } 2 \text { nd field (inspirational } \\
\text { motivation) }\end{array}$} & 2.42 & 0.29 & High & \\
\hline \multicolumn{6}{|c|}{ 3rd field (intellectual stimulation) } \\
\hline 11 & Allow some calculated risk & 2.16 & 0.59 & Medium & 7 \\
\hline 12 & $\begin{array}{l}\text { Urging workers to be innovative and } \\
\text { creative at work }\end{array}$ & 2.47 & 0.70 & High & 4 \\
\hline 13 & $\begin{array}{l}\text { Confidence in the capabilities and skills } \\
\text { of workers }\end{array}$ & 2.65 & 0.49 & High & 2 \\
\hline 14 & $\begin{array}{l}\text { Realizing the importance of change for } \\
\text { the better }\end{array}$ & 2.41 & 0.62 & High & 5 \\
\hline 15 & $\begin{array}{l}\text { Establishing the concept of participation } \\
\text { among workers }\end{array}$ & 2.52 & 0.64 & High & 3 \\
\hline 16 & $\begin{array}{l}\text { Hear workers' views on solving business } \\
\text { problems }\end{array}$ & 2.68 & 0.53 & High & 1 \\
\hline 17 & The ability to foresee the future & 2.20 & 0.69 & Medium & 6 \\
\hline \multicolumn{2}{|c|}{$\begin{array}{l}\text { Overall average of the } 3 \text { rd field (intellectual } \\
\text { stimulation) }\end{array}$} & 2.44 & 0.25 & High & \\
\hline \multicolumn{6}{|c|}{ 4th field (individual considerations) } \\
\hline 18 & $\begin{array}{l}\text { Take care to clarify the business goals } \\
\text { for workers }\end{array}$ & 2.46 & 0.64 & High & 2 \\
\hline 19 & $\begin{array}{l}\text { Identify the needs of workers and try to } \\
\text { meet them }\end{array}$ & 2.02 & 0.65 & Medium & 6 \\
\hline 20 & $\begin{array}{l}\text { Consider individual differences between } \\
\text { workers }\end{array}$ & 2.12 & 0.69 & Medium & 5 \\
\hline 21 & Transparency in dealing with workers & 2.42 & 0.67 & High & 3 \\
\hline 22 & $\begin{array}{l}\text { Listen attentively to the opinions of } \\
\text { workers }\end{array}$ & 2.52 & 0.58 & High & 1 \\
\hline 23 & $\begin{array}{l}\text { Commitment to the principle of justice } \\
\text { and equality in dealing with workers }\end{array}$ & 2.37 & 0.57 & High & 4 \\
\hline 24 & $\begin{array}{l}\text { Understand the conditions and feelings } \\
\text { of workers }\end{array}$ & 1.89 & 0.61 & Medium & 7 \\
\hline \multicolumn{2}{|c|}{$\begin{array}{l}\text { Overall average for 4th field (individual } \\
\text { considerations) }\end{array}$} & 2.26 & 0.31 & Medium & \\
\hline \multicolumn{6}{|c|}{ 5th field (empowerment) } \\
\hline 25 & $\begin{array}{l}\text { Encouraging employees to take } \\
\text { responsibility }\end{array}$ & 2.44 & 0.59 & High & 1 \\
\hline 26 & Delegating some powers to workers & 2.40 & 0.60 & High & 3 \\
\hline 27 & $\begin{array}{l}\text { Encourage entrepreneurship among } \\
\text { workers }\end{array}$ & 2.20 & 0.59 & Medium & 6 \\
\hline 28 & $\begin{array}{l}\text { Create an atmosphere in which workers } \\
\text { feel satisfied }\end{array}$ & 2.35 & 0.62 & High & 4 \\
\hline 29 & $\begin{array}{l}\text { Recruitment and investment of workers } \\
\text { capabilities }\end{array}$ & 2.41 & 0.59 & High & 2 \\
\hline 30 & $\begin{array}{l}\text { Encouraging workers to achieve } \\
\text { performance excellence }\end{array}$ & 2.36 & 0.60 & High & 5 \\
\hline \multicolumn{2}{|c|}{ Overall average for 5th field (empowerment) } & 2.36 & 0.28 & High & \\
\hline
\end{tabular}


It is clear from Table 4 that the arithmetic mean for the 1st field (good example) ranges from 2.48 to 2.68, and all items of this field have a high degree of approval from the members of the research sample. In addition, the arithmetic mean for the 2 nd field (inspirational stimulation) ranges from 2.14 to 2.71 , and 4 items have a high degree of approval, while two items obtained an average degree of approval by the sample individuals search.

Regarding the 3rd field (intellectual stimulation), it shows that the arithmetic mean for the items intellectual stimulation ranges from 2.16 to 2.68, and 5 items obtained a high degree of approval, while 2 items have an average degree of approval by the members of the research sample. For the 4th field (individual considerations), the arithmetic mean ranges from 1.89 to 2.52 , and 4 items have a high degree of approval, the 3 remaining items have an average degree of approval from beside the individuals in the study sample. Concerning the 5th field (empowerment), the arithmetic averages ranges from 2.20 to 2.44, and it observed that 5 items have a high degree of approval, while 1 item has an average degree of approval by the sample of individuals.

The empirical evidence of the answer to the first question indicates that the degree of managerial leadership practicing transformational leadership at Shaqra University from the viewpoint of its employees is high. These results are consistent with the findings of Al-Thuwaini (2014), Al-Rashidi, (2017), Al-Somali and Metwally (2018), Al-Maani and Al-Kharabsheh (2016), Al-Saleh (2019) and Assaf and Hassanein (2019). These results can be explained in light of Shaqra University's adoption during the past years to spread a culture of quality that requires adopting modern leadership styles to achieve quality standards and academic accreditation for the university and colleges.

These results can also be explained in light of the conviction of the administrative leaders at Shaqra University of the positive role of a good example in motivating the department employees to carry out their tasks to the fullest. They strive to provide model and role models for employees by committing to work seriously, and completing work and tasks on time.

The modern theories in the field of leadership also confirm that the method of motivating others by providing a good example is the common method in many institutions that seek to develop and change for the better. It includes the administrative leader's keenness to deal with vague and complex situations and face difficulties with courage to maintain a better level of performance, and to turn visions into a tangible reality, and strive to achieve productivity beyond what is expected, by encouraging workers to solve problems in innovative ways, and to delegate workers with them in some powers.

This will be in order to achieve the desired goals, work to support the team spirit, inform the workers about the overall goals of the work, and express their appreciation for the efforts made by the workers. This will be in order to achieve these goals, and they will arouse them in motivation and motivate them to face the difficult conditions that they may face in the work in order to pray together. To the desired vision, and instill in them the inspiration to solve the problems that may prevent the achievement of the desired goals, and to increase awareness and understanding of the desired goals. Administrative leaders are convinced that their actions affect the behavior of employees and their performance of work.

\section{Outcomes of Answering to "Question 2"}

The second question states, "What is the degree of organizational commitment among workers at Shaqra University?" To answer this question, arithmetic averages and standard deviations for the responses of the individuals in the research sample were calculated on each of the fields of the second axis (the organizational commitment to the questionnaire and for each of the items of each field. The results are reported in Table 5. 
Table 5. Arithmetic Averages, Standard Deviations, Degree of Approval, And Ranking Of Fields: Second Axis (Organizational Commitment)

\begin{tabular}{|l|l|c|c|c|c|}
\hline No & \multicolumn{1}{|c|}{ Paragraph } & $\begin{array}{c}\text { Arithmetic } \\
\text { Average }\end{array}$ & $\begin{array}{c}\text { Standard } \\
\text { Deviation }\end{array}$ & $\begin{array}{c}\text { Degree of } \\
\text { Approval }\end{array}$ & Ranking \\
\hline 1 & $\begin{array}{l}\text { The first field: loyalty to the } \\
\text { university }\end{array}$ & 2.55 & 0.24 & High & 2 \\
\hline 2 & $\begin{array}{l}\text { The second field: responsibility } \\
\text { towards the university }\end{array}$ & 2.63 & 0.29 & High & 1 \\
\hline 3 & $\begin{array}{l}\text { The third field: the desire to } \\
\text { continue working }\end{array}$ & 2.51 & 0.24 & High & 3 \\
\hline $\begin{array}{l}\text { Overall average of the second axis } \\
\text { (organizational commitment) }\end{array}$ & 2.56 & 0.13 & High & \\
\hline
\end{tabular}

Table 5 indicates that the mean of the total score for the second axis (organizational commitment) reached (2.56), with a standard deviation of 0.13 , and with a high degree of approval. The arithmetic mean fields of this axis ranges from 2.51 to 2.63, with a high degree of approval for all fields by the individuals in the study sample. The order of these fields came according to the degree of approval by the members of the sample under study as follows: responsibility towards the university, then loyalty to the university, then the desire to continue working in the university. The following are the arithmetic averages and the standard deviations for the items for each of these fields:

- $\quad$ First field (loyalty to the university)

- $\quad$ Second field (responsibility towards the university)

- $\quad$ Third field (the desire to continue working in the university)

Table 6. Results of the First to Third Fields of the Second Axis (Loyalty to the University, Responsibility towards the University, and the Desire to Continue Working in the University)

\begin{tabular}{|c|c|c|c|c|c|}
\hline No & Fields & $\begin{array}{c}\text { Arithmetic } \\
\text { Average }\end{array}$ & $\begin{array}{l}\text { Standard } \\
\text { Deviation }\end{array}$ & $\begin{array}{l}\text { Degree of } \\
\text { Approval }\end{array}$ & Ranking \\
\hline \multicolumn{6}{|c|}{ 1st field (loyalty to the university) } \\
\hline 31 & $\begin{array}{l}\text { I feel happy when performing the tasks } \\
\text { assigned to me }\end{array}$ & 2.58 & 0.54 & High & 3 \\
\hline 32 & $\begin{array}{l}\text { I make sure to do my best at the } \\
\text { university }\end{array}$ & 2.81 & 0.46 & High & 1 \\
\hline 33 & See what is new for my performance & 2.19 & 0.68 & Medium & 6 \\
\hline 34 & I respect university employment laws & 2.73 & 0.52 & High & 1 \\
\hline 35 & $\begin{array}{l}\text { I see that my values are consistent with } \\
\text { those of the university }\end{array}$ & 2.51 & 0.57 & High & 4 \\
\hline 36 & $\begin{array}{l}\text { I talk about the university in a positive } \\
\text { way in front of others }\end{array}$ & 2.48 & 0.70 & High & 5 \\
\hline \multicolumn{2}{|c|}{$\begin{array}{l}\text { Overall average for the } 1 \text { st field (loyalty to the } \\
\text { university) }\end{array}$} & 2.55 & 0.24 & High & \\
\hline \multicolumn{6}{|c|}{ 2nd field (responsibility towards the university) } \\
\hline 37 & $\begin{array}{l}\text { I am interested in the reputation and } \\
\text { future of the university }\end{array}$ & 2.65 & 0.57 & High & 5 \\
\hline 38 & $\begin{array}{l}\text { I do my best to achieve the goals of the } \\
\text { university }\end{array}$ & 2.52 & 0.63 & High & 8 \\
\hline 39 & I maintain university properties. & 2.73 & 0.53 & High & 2 \\
\hline 40 & $\begin{array}{l}\text { I consider university problems as my } \\
\text { own }\end{array}$ & 2.66 & 0.57 & High & 4 \\
\hline 41 & I am ready to do more for the & 2.77 & 0.45 & High & 1 \\
\hline
\end{tabular}




\begin{tabular}{|c|c|c|c|c|c|}
\hline & university's success & & & & \\
\hline 42 & $\begin{array}{l}\text { I accept any work entrusted to be } \\
\text { executed at the university }\end{array}$ & 2.61 & 0.62 & High & 6 \\
\hline 43 & $\begin{array}{l}\text { I offer support and support to my } \\
\text { university colleagues }\end{array}$ & 2.67 & 0.53 & High & 3 \\
\hline 44 & $\begin{array}{l}\text { I present the university's interest with } \\
\text { my personal interests }\end{array}$ & 2.51 & 0.67 & High & 9 \\
\hline 45 & I do my required tasks to the fullest & 2.59 & 0.61 & High & 7 \\
\hline \multicolumn{2}{|c|}{$\begin{array}{l}\text { Overall average for 2nd field (responsibility } \\
\text { towards the university) }\end{array}$} & 2.63 & 0.19 & High & \\
\hline \multicolumn{6}{|c|}{ 3rd field (the desire to continue working in the university) } \\
\hline 46 & $\begin{array}{l}\text { I hope to continue this university until } \\
\text { retirement age }\end{array}$ & 2.61 & 0.56 & High & 3 \\
\hline 47 & $\begin{array}{l}\text { I avoid absenteeism as much as } \\
\text { possible }\end{array}$ & 2.48 & 0.67 & High & 5 \\
\hline 48 & $\begin{array}{l}\text { I refuse to transfer from this university } \\
\text { to any other university }\end{array}$ & 2.53 & 0.57 & High & 4 \\
\hline 49 & $\begin{array}{l}\text { I commit to carrying out my work } \\
\text { assignments during the official working } \\
\text { hours at the university }\end{array}$ & 2.67 & 0.52 & High & 2 \\
\hline 50 & $\begin{array}{l}\text { The university climate encourages } \\
\text { work }\end{array}$ & 2.69 & 0.49 & High & 1 \\
\hline 52 & $\begin{array}{l}\text { Leaving college will cause me a lot of } \\
\text { trouble }\end{array}$ & 2.13 & 0.58 & Medium & 7 \\
\hline 52 & $\begin{array}{l}\text { Continuing to work at university is } \\
\text { essential for me }\end{array}$ & 2.43 & 0.58 & High & 6 \\
\hline \multicolumn{2}{|c|}{$\begin{array}{l}\text { Overall average of the } 3 \text { rd field (the desire to } \\
\text { continue working in the university) }\end{array}$} & 2.51 & 0.24 & High & \\
\hline
\end{tabular}

Table 6 shows that the arithmetic mean for the 1st field (loyalty to the university) ranges from 2.19 to 2.81 , and 5 items have a high degree of approval, while 1 item has an average degree of approval by the participants. Regarding the 2nd field (responsibility towards the university), it shows that the arithmetic mean for the items of responsibility towards the university ranges from 2.51 to 2.77 , and all the items have a high degree of approval by the participants.

For the 3rdfield (the desire to continue to work in the university), the arithmetic mean for this item ranges from 2.13 to 2.69 , and 6 items have a high degree of approval, while 1 item has an average degree of approval medium by members of the research sample. The results of the answer to the 2nd question indicate that the degree of organizational commitment of workers at Shaqra University is high. These results are consistent with the results of the studies of Bell (2012), Al-Babtain (2014), Al-Sayyan (2015), Essa (2016), Safar (2017), Al-Muaini (2018) and Abu Shaqr and Jubran (2019).

These results can be explained in light of the keenness of the employees of Shaqra University to advance their university, which reflects positively on the degree of their organizational commitment, the high level of their sense of loyalty and responsibility towards their work, and their desire to continue their work. These results can also be explained in light of the keenness of Shaqra University employees to continue their work. They are looking forward to continuing to work in their university, and participating in activities that raise the level of work with them because of their feeling that what the university is achieving is beneficial and beneficial to them, and then increases their sense of belonging to the university and keenness to improve and develop work in it. 


\section{Outcomes of Answering to "Question 3"}

The third question states "What is the relationship between the practice of administrative leaders of transformational leadership and organizational commitment among workers at Shaqra University?" To answer this question, the value of the Pearson linear correlation coefficient between the degrees of individuals of the research community on the axis of transformational leadership and their degrees on the axis of organizational commitment was calculated. The results are reported in Table 7.

Table 7. The Coefficient of Pearson's Linear Correlation between the Degrees of Individuals on the Axis of Transformational Leadership and their Degrees on the Axis of Organizational Commitment

\begin{tabular}{|l|c|c|}
\hline \multicolumn{1}{|c|}{ Variables } & Correlation coefficient & Significance level \\
\cline { 1 - 1 } Transformational Leadership & 0.64 & 0.01 \\
\cline { 1 - 2 } Organizational commitment & 0.64 & 0.01 \\
\hline
\end{tabular}

It is observed from Table 7 that the value of Pearson's linear correlation coefficient between the degrees of individuals in the research community on the axis of transformational leadership and their degrees on the axis of organizational commitment amounted to (0.64), which is a statistically significant value at the $1 \%$ level. The results of the answer to the third question indicate that there is a positive relationship between the practice of administrative leaders of transformational leadership and the organizational commitment of workers at Shaqra University.

Among the previous studies, the researcher did not find a study that dealt with the relationship between the practice of administrative leaders of transformational leadership and the organizational commitment of workers at the university. This is unique to the current research on previous studies. However, our results are in line with the study of Qasim (2011), suggesting that the original driving behaviors affect as an intermediate variable the strength of the positive relationship between the quality of the career life workers and their sense of organizational commitment. The results corroborate the findings of Tahir, Tina and Daud (2014), showing a positive association between transformational leadership and academic commitment. Our results also agree with the results of Somali and Mitwalli (2018), indicating a positive relationship between transformational leadership and empowerment and creativity of administrative staff.

These results can be explained in light of the greater the degree of administrative leadership exercising transformational leadership, the more it motivates university employees to commit to the tasks assigned to them, and the more they feel that they are part of the institution, and that the goals of the institution are personal goals for them. University workers need those who motivate and encourage them in order to achieve their organizational commitment, which is achieved in the transformational leadership style. The university's administrative leaderships were keen to provide a supportive climate in which the leader listens carefully to the individual subordinates 'needs, and to look at each individual and his needs separately, this would increase the level of organizational commitment among workers. In addition to the university's administrative leadership's practice of transformational leadership, it would strengthen the university's employees 'sense of cohesion in its work team, and encourage them to work in a team spirit, which increases their sense of pride as a result of belonging to the university and their commitment to achieving its goals. Employees 'awareness of the ability of administrative leaders to face difficult situations in work through appropriate strategies increases the employees' sense of belonging to their university, which is reflected positively by their association with the university and their organizational commitment to it.

\section{Outcomes of Answering to "Question 4"}

The fourth question states, "are there statistically significant differences in the degree of administrative leadership exercising transformational leadership at Shaqra University from the viewpoint of its employees attributable to the variables of gender, educational qualification or years of experience?" To answer this 
question, $T$ - test and one way ANOVA test are used to detect the differences in the degree of organizational commitment of workers at Shaqra University, which may be attributed to the gender variable and the educational qualification or years of experience. The results are reported in Table 8.

Table 8. Results of the T-test to Detect the Differences in the Degree of Administrative Leadership Exercising Transformational Leadership Attributed to the Gender Variable

\begin{tabular}{|l|c|c|c|c|c|c|c|}
\hline Variable & Type & Number & $\begin{array}{c}\text { Arithmetic } \\
\text { Average }\end{array}$ & $\begin{array}{c}\text { Standard } \\
\text { Deviation }\end{array}$ & $\begin{array}{c}\text { Degree } \\
\text { of free }\end{array}$ & Value & $\begin{array}{c}\text { Significance } \\
\text { level }\end{array}$ \\
\hline $\begin{array}{l}\text { Transformational } \\
\text { leadership }\end{array}$ & Male & 140 & 2.40 & 0.15 & 229 & 0.96 & 0.34 \\
\cline { 2 - 9 } & Female & 91 & 2.42 & 0.13 & 229 & \multirow{2}{*}{ fevel } \\
\hline
\end{tabular}

Table 8 shows that there are no statistically significant differences in the mean scores of the approval of the research sample members on the practice of administrative leaders of transformational leadership in Shaqra University that is attributed to the type variable. Table 9 presents the results of the unidirectional and oneway analyses of variance to reveal the differences in the degree of administrative leadership practice of transformational leadership at Shaqra University from the viewpoint of its employees, which may be attributed to the variable of the academic qualification.

Table 9. Results of the Unidirectional and One-Way Analyses of Variance to Detect the Differences in the Degree of Administrative Leadership Exercising Transformational Leadership

\begin{tabular}{|c|c|c|c|c|c|c|}
\hline Variable & $\begin{array}{c}\text { Source of } \\
\text { contrast }\end{array}$ & $\begin{array}{c}\text { Source of } \\
\text { contrast }\end{array}$ & $\begin{array}{c}\text { Degrees of } \\
\text { freedom }\end{array}$ & $\begin{array}{c}\text { Average } \\
\text { square }\end{array}$ & $\begin{array}{c}\text { Percentage } \\
\text { "F" }\end{array}$ & $\begin{array}{c}\text { Significance } \\
\text { level }\end{array}$ \\
\hline \multicolumn{7}{|c|}{ Unidirectional analysis of variance } \\
\hline \multirow{3}{*}{$\begin{array}{l}\text { Transformational } \\
\text { leadership }\end{array}$} & $\begin{array}{l}\text { Between } \\
\text { groups }\end{array}$ & 0.02 & 2 & 0.01 & \multirow{3}{*}{0.59} & \multirow{3}{*}{0.5} \\
\hline & $\begin{array}{l}\text { Within } \\
\text { groups }\end{array}$ & 4.68 & 228 & 0.02 & & \\
\hline & $\begin{array}{l}\text { Total } \\
\text { variance }\end{array}$ & 4.70 & 230 & & & \\
\hline \multicolumn{7}{|c|}{ One-way analysis of variance } \\
\hline \multirow{3}{*}{$\begin{array}{l}\text { Transformational } \\
\text { leadership }\end{array}$} & $\begin{array}{l}\text { Between } \\
\text { groups }\end{array}$ & 0.05 & 2 & 0.02 & \multirow{3}{*}{1.12} & \multirow{3}{*}{0.33} \\
\hline & $\begin{array}{l}\text { Within } \\
\text { groups }\end{array}$ & 4.66 & 228 & 0.02 & & \\
\hline & $\begin{array}{l}\text { Total } \\
\text { variance }\end{array}$ & 4.70 & 230 & & & \\
\hline
\end{tabular}

The results presented in Table 9 indicate that there are no statistically significant differences in the degree of managerial leadership practicing transformational leadership in Shaqra University from the viewpoint of its employees attributed to gender, educational qualification or years of experience. These results are consistent with the results of Khalaf (2010), Al-Thuwaini (2014). Meanings and Kharabsheh (2016), AlTuwaijri (2017), Atom (2018) and Al-Saleh (2019).

These results can also be explained in the light of the fact that the workers at Shaqra University, regardless of the different years of their experience or their scientific qualifications, work in the same work environment, and they live with the same conditions that relate to work.

The individual's perception of them is not different according to the different demographic variables of interest in the current research. The similarity in the previous circumstances is accompanied by an agreement in the regulations, systems and laws that apply to all employees regardless of type, educational qualification or years of experience. 


\section{Outcomes of Answering to "Question 5"}

The fifth question states, "Are there statistically significant differences in the degree of organizational commitment of workers at Shaqra University attributable to the variables of type, educational qualification or years of experience?" To answer this question, a $T$ - test was used to detect differences in the degree of organizational commitment of workers at Shaqra University, which may be attributed to the gender variable. One Way ANOVA test was used to detect the differences in the degree of organizational commitment of workers at Shaqra University, which may be attributed to the variables of the educational qualification or years of experience. The results are reported in Table 10.

Table 10. Results of the $T$-test to Reveal the Differences in the Degree of Organizational Commitment among Workers Attributed to the Gender Variable

\begin{tabular}{|l|c|c|c|c|c|c|c|}
\hline Variable & Type & Number & $\begin{array}{c}\text { Arithmetic } \\
\text { Average }\end{array}$ & $\begin{array}{c}\text { Standard } \\
\text { Deviation }\end{array}$ & $\begin{array}{c}\text { Degree } \\
\text { of free }\end{array}$ & Value & $\begin{array}{c}\text { Significance } \\
\text { level }\end{array}$ \\
\cline { 1 - 8 } $\begin{array}{l}\text { Transformational } \\
\text { leadership }\end{array}$ & Male & 140 & 2.56 & 0.13 & 229 & 0.12 & 0.91 \\
\cline { 2 - 6 } & Female & 91 & 2.57 & 0.12 & & 0.12 \\
\hline
\end{tabular}

Table 10 shows that there are no statistically significant differences in the mean levels of organizational commitment for workers at Shaqra University, which are attributable to the type variable. Table 11 reports the results of the unidirectional and one-way analyses of variance to detect the differences in the degree of organizational commitment among workers at Shaqra University, which may be attributed to the variable of the educational qualification.

Table 11. Results of the Unidirectional and One-Way Analyses Of Variance to Detect the Differences in the Degree of Organizational Commitment among Workers

\begin{tabular}{|c|c|c|c|c|c|c|}
\hline Variable & $\begin{array}{c}\text { Source of } \\
\text { contrast }\end{array}$ & $\begin{array}{l}\text { Source of } \\
\text { contrast }\end{array}$ & $\begin{array}{c}\text { Degrees of } \\
\text { freedom }\end{array}$ & $\begin{array}{l}\text { Average } \\
\text { square }\end{array}$ & $\begin{array}{c}\text { Percentage } \\
\text { "F" }\end{array}$ & $\begin{array}{c}\text { Significance } \\
\text { level }\end{array}$ \\
\hline \multicolumn{7}{|c|}{ Unidirectional analysis of variance } \\
\hline \multirow{3}{*}{$\begin{array}{l}\text { Transformational } \\
\text { leadership }\end{array}$} & $\begin{array}{l}\text { Between } \\
\text { groups }\end{array}$ & 0.06 & 2 & 0.03 & \multirow{3}{*}{1.99} & \multirow{3}{*}{0.14} \\
\hline & $\begin{array}{l}\text { Within } \\
\text { groups }\end{array}$ & 3.54 & 228 & 0.02 & & \\
\hline & $\begin{array}{l}\text { Total } \\
\text { variance }\end{array}$ & 3.60 & 230 & & & \\
\hline \multicolumn{7}{|c|}{ One-way analysis of variance } \\
\hline \multirow{3}{*}{$\begin{array}{l}\text { Transformational } \\
\text { leadership }\end{array}$} & $\begin{array}{l}\text { Between } \\
\text { groups }\end{array}$ & 0.01 & 2 & 0.01 & \multirow{3}{*}{0.20} & \multirow{3}{*}{0.82} \\
\hline & $\begin{array}{l}\text { Within } \\
\text { groups }\end{array}$ & 3.59 & 228 & 0.02 & & \\
\hline & $\begin{array}{l}\text { Total } \\
\text { variance }\end{array}$ & 3.60 & 230 & & & \\
\hline
\end{tabular}

The results presented in Table 11 indicate that there are no statistically significant differences in the degree of organizational commitment of workers at Shaqra University attributable to the variables of gender, educational qualification or years of experience. These results are consistent with the results of Al-Siyani (2015), indicating that there are no statistically significant differences in organizational commitment due to age, qualification, or career status variables. Our results also agree with the results of the study of Abu Ashqar and Jibran (2019), suggesting statistically significant differences in organizational commitment in Jordanian universities attributable to the gender variables and college variables. However, these results differ with the results of Al-Babtain (2014), which found a statistically significant difference in the degree of organizational commitment among department heads in the colleges of Salman bin Abdulaziz University, due to the variable of good female sex). 
These results can be explained in light of the fact that the workers at Shaqra University coexist with the same conditions at work. They have the same capabilities, and they get the same rewards at work, and then there are no differences between them in the degree of organizational commitment attributable to gender changes, or the educational qualification, or years of experience.

On the other hand, workers at the university of different specializations and academic qualifications and the number of years of their experience spend long times at work, and then the presence at the university, affiliation with it and the pursuit of its goals becomes an integral part of their lives. This is in addition to the fact that the workers, through what they find as a result of their effort, appear to be at the level of the performance of their university and the appreciation of the community surrounding them for these efforts increases their sense of organizational commitment to the university.

\section{Conclusion and Recommendations}

The main objective of this study is to identify the degree of practicing the transformational leadership at Shaqra University from the view of its employees, the degree of organizational commitment among the employees, and also the relationship between practicing transformational leadership and organizational commitment among the employees to detect the differences in both of transformational leadership and organizational commitment among the employees relative to sex, educational qualification or experience. A stratified random sample $(N=231)$ of employees of Shaqra University was interviewed.

The empirical evidence shows that the degree of practicing the transformational leadership from the view of its employees as well as the degree of organizational commitment among the employees is found to be high. The evidence also indicates that there is a statistically significant relationship between practicing transformational leadership and organizational commitment among the employees.

However, no statistically significant differences in both of transformational leadership and organizational commitment among the employees were detected. This result is due to the heterogeneous related to sociodemographic characteristics like sex, educational qualification, or experience years.

In light of the foregoing outcomes, we suggested the following recommendations:

- Organizing training courses for administrative leaders in universities to increase their awareness of the importance of transformational leadership and its long-term benefits in developing employee performance.

- Increasing interest by university departments in taking measures that increase the level of organizational commitment among workers.

- The human resources department takes the necessary measures to raise the motivation of employees towards better performance and motivate them to progress and develop

- Involving university employees in decision-making and making them aware of the importance of active participation in community activities.

- Work on developing the organizational commitment of workers in universities through training courses to develop a sense of belonging, clarifying the goals and strategies of the university periodically, and urging workers to exert effort and dedication to work.

- Providing an atmosphere of understanding between administrative leaders and university employees, while creating a work environment that supports opportunities for positive participation of workers in planning and setting work goals.

- The need to pay attention to empowering university workers by strengthening their roles as decisionmaking participants in work teams. 


\section{References}

Abd al-Rahman, Sayyar, (2014), “Effective driving, Alexandria: Dar Al-WafaDunia for Printing and Publishing.

Abu Al-Nasr, Medhat Mohamed, (2009), "Future Leaders: The New Outstanding Leadership", Cairo: The Arab Group for Training and Publishing.

Abu Shaqr, Rawan Khidr and Jibran, Ali Mohamed, (2019), "The reality of organizational commitment of faculty members in Jordanian public and private universities, its obstacles, and ways to improve its level from their point of view", Educational Sciences Studies, vol. 46, no.1: 713-729.

Al-Ajami, Hussein, (2010), "Modern trends in administrative leadership and human development", Amman: Al Masirah House for Publishing and Distribution.

Al-Amiri, Ahmed Salem, (2002), "Transformational leadership behavior and organizational citizenship behavior in agencies Saudi government", Arab Journal of Administrative Sciences,vol. 9, no. 1: 1939.

Al-Babtain, Abdul Rahman Bin Abdul Wahab, (2014), “The degree of organizational commitment of department heads in the colleges of Salman bin Abdulaziz University, Saudi Journal of Higher Education, Center for Research and Studies in Higher Education, vol. 11: 123-160.

Alduraish, Muhammad Ahmed, (2008), "Organizational commitment theory", Cairo: Books World Publishing House.

Allen N., Meyer J., (1997), "Commitment in the workplace: Theory, research, and application", California: Sage.

Al-Ma'ani, Ayman Awda and Al-Kharabsheh, Omar Muhammad, (2016), "The effect of applying transformational leadership on administrative creativity among workers at Al-Balqa Applied University" Educational Journal, vol. 121: 117-169.

Al-Masry, Ehab Issa and Amer, Tariq Abdel-Raouf, (2013), “'Organizational behavior and organizational behavior. Cairo: Arab Foundation for Science and Culture.

Al-Muaini, Hashem Rashid, (2018), "Organizational justice and its impact on organizational commitment in Jordanian private universities: job satisfaction as an intermediate variable", Unpublished Master Thesis, College of Economics and Administrative Sciences, Al Al-Bayt University, Jordan.

Al-Nuwaqa, Atallah Bashir, (2013), "The effect of organizational confidence in achieving organizational commitment among workers at Taif University", Egyptian Journal of Business Studies, Faculty of Commerce, Mansoura University, vol. 37, no. 2: 155-190.

Al-Otaibi, Saad, (2016), "The impact of transformational leadership on the psychological empowerment of workers in companies the private sector in Riyadh", Arab Journal of Management, vol. 36, no. 1: 213238.

Al-Rashidi, Ali Dabian, (2017). Transformational leadership and its relationship to organizational creativity of deans and heads of departments in governmental and private universities in Riyadh, The Arab Journal of Security Studies, vol. 33, no. 4: 3-39.

Al-Saleh, Muhammad Bin Ali, (2019), "Transformational leadership for academic leaders in Saudi universities: Practice and empowerment', Educational Sciences, vol. 46, no. 3: 444-465.

Al-Siyani, Majed Qasim, (2015), "Measuring the level of organizational commitment in Yemeni private universities: a field study on private universities in governorate", Journal of Administrative Sciences, Faculty of Administrative Sciences, University of Aden, vol. 11, no. 5: 109-143.

Al-Thuwaini, Tariq Bin Muhammad, (2014), "The degree of the practice of heads of academic departments at King Saud University of the transformational leadership style from the viewpoint of faculty members", Education and Psychology Thesis, King Saud University, vol. 44: 147-165.

Al-Tuwaijri, Hayla, 2017, Transformational leadership and its relationship to the effectiveness of decisionmaking among heads of educational supervision departments in Buraidah city in the Qassim region, Journal of Educational and Psychological Sciences, vol. 18, no. 2: 647-611.

Assaf, Mahmoud Abdel-Majid and Hassanein, Abdullah Mustafa, (2019), "The extent of transformational leadership in Palestinian universities in the southern governorates from the viewpoint of faculty members", The Arab Journal for Quality Assurance in University Education, vol. 41, no. 12: 3-26-29. 
Balay R., (2012), "Effect of learning organization perception to the organizational commitment: a comparison between private and public university', Educational sciences: Theory \& practice, vol. 12, no. 4: 2474-2486.

Battah, Ahmed, (2006), Contemporary Issues in Educational Administration. Amman: Dar Al-Shorouk.

Bayram H., Din S., (2015), "Role of transformational leadership on employee's job satisfaction: The case of private universities in Bosnia and Herzegovina', European researcher, vol. 93, no. 4: 270-281.

Brown D., Armstrong M., (2006), 'Strategic reward: Making it happen', London: Kogan page publishers.

Burns J., (1978), Leadership. New York: Harper \& Row.

Burns J., (2004), “Trangforming leadership: A new pursuit of happiness”, New York: Grove Press.

Conger M., (2002), “Leadership: learning to share the vision”, Organizational dynamics, vol. 19, no. 3: 19-31.

Dahleys, Khaled, (2018), "The impact of servant leadership on organizational commitment in academic institutions, Palestinian', Jordanian Journal of Business Administration, vol. 14, no. 3: 465-494.

Faris, Muhammad Jawdat, (2014), "The relationship between organizational confidence and organizational commitment: a field study on Al-Azhar University - Gaza', Journal of the Islamic University for Economic and Administrative Studies, Islamic University of Gaza,vol. 22, no. 2: 165-195.

Flih, Farouq Abdo and Abdul Majeed, Mr. Muhammad, (2005), "Organizational behavior in the management of educational institutions", Amman: Al Masirah Publishing House.

Hafez, Muhammad Sabri, al-Maghidi, Hassan bin Muhammad, Mahmoud, al-Sayyid, (2013), "Leadership in educational institutions', Cairo: Dar Al Alam Al Kutub for Printing and Publishing.

Issa, Ahmed El-Sayed, (2016), "The effect of applying spiritual leadership on organizational commitment: an applied study on the employees of Taif University', Trade and Finance Journal, Faculty of Commerce, Tanta University, vol. 2: 134-180.

Khalaf, Muhammad Karim, (2010), "The relationship of transformational leadership to managerial creativity among academic department heads at the Islamic University of Gaza', Unpublished Master Thesis, College of Commerce, Islamic University, Gaza.

Khawaldeh, Ayed and Jaradat, Muhammad, (2011), "The degree to which deans of faculties and faculty at the University of Jerash practice transformational leadership behavior', Journal of Specific Education Research, Mansoura University, vol. 23, no. 1: 1-30.

Klein H., Becker T., Meyer J., (2012), "Commitment in organizations: Accumulated wisdom and new directions", London: Routledge.

Loving, Sami Ibrahim, (2006), "Measuring the level of organizational commitment of workers in the Palestinian universities in the Gaza Strip', Unpublished Master Thesis, College of Commerce, Islamic University, Gaza.

Meyer J., (2016), “'Handbook of employee commitment', London: Edward Elgar publishing.

Nwadei A., (2004), "The relationship between perceived values congruence and organizational commitment in multinational organization', New York: Universal- publishers.

Ortega G., Freites Z., (2019), "Model of relationship of transformational leadership and university management", DYNA, vol. 86: 9-16.

Otoom, Yomna Ahmed, (2018), “The relationship between transformational leadership dimensions and managerial creativity from the point of view Faculty members at Imam Abdul Rahman bin Faisal University', King Abdulaziz University magazine Arts and Humanities, vol. 26, no. 2: 233-258.

Pongpearchan P., (2016), "Effect of transformational leadership and high performance work system on job motivation and task performance: Empirical evidence from business schools of Thailand universities", Journal of business and retail management research, vol. 10, no. 3: 93-105.

Pushpika T., (2019), "The effect of organizational commitment and job satisfaction on organizational citizenship behavior of the academic staff members in public sector universities in Sri Lanka', International journal of recent advances in organizational behaviour and decision sciences, vol. 5, no. 1: 1233-1251.

Qasim, Mervat Ibrahim, (2011), "The effect of indigenous leadership as an intermediate variable on the relationship between quality of work life and organizational commitment: a field study", Scientific Journal of Economics and Commerce, Faculty of Commerce, Ain Shams University, vol. 3: 544-561. 
Radwan, Mahmoud Abdel-Fattah, (2012), "Leadership and motivation skills for subordinates", Cairo: The Group Arab Training and Publishing.

Rashid, Mazen Fares, (2003), "Emotional Intelligence and Transformational Leadership", Journal of Commercial Research, vol. 12: 493-464.

Sadeghi A., Pihie Z., (2012), "Transformational leadership and its predictive effects on leadership effectiveness", International journal of business and social science, vol. 7, no. 3: 186-197.

Safar, Manal Abdel Rahman, (2017), "Job empowerment and its role in enhancing organizational loyalty among female employees of Umm Al-Qura University", Educational Sciences Studies,vol. 44, no. 4; 299-313.

Schermerhorn J., Osborn R., Bien M., Hunt J., (2011), “Organizational behavior. New York: John Wiley\& Sons.

Somali, Sabah bint Abdullah and Metwally, Razan Farid, (2018), "The Impact of Transformational Leadership on Tamkeen Creativity of Administrative Personnel in Higher Education Institutions: An Empirical Study on Administrative Staff at King Abdulaziz University in the Kingdom of Saudi Arabia', Journal of Economic, Administrative and Legal Sciences, vol. 9, no. 3: 38-18.

Suhana S., Udin S., Fuad M., (2019), "Transformational leadership and innovative behavior: The mediating role of knowledge sharing in indonesian private university", International journal of higher education, vol. 8, no. 6: 15-25.

Tahir L., Tina A., Daud K., (2014), “Academics transformational leadership: an investigation of heads of department leadership behaviours in Malaysian public universities", Journal of educational studies, vol. 40, no. 5: 473-495.

Taner B., Turhan M., Helvaci H., (2015), "The effect of the leadership perception and organizational justice on organizational commitment: a research in a state university", International Review of Management and Marketing, vol. 5, no. 3: 180-194.

Tiwari S., (2009), "Psychological perspectives of organizational commitment", New Delhi: Concept publishing company.

Ugwu C., (2019), "Mediation effect of knowledge management on the relationship between transformational leadership and job performance of librarians in university libraries in Nigeria", Journal of librarianship and information science, vol. 51, no. 1: 1052-1066.

Wesson M., Jeffery J., Colquitt J., (2016), "Organizational behavior: Improving performance and commitment in the workplace", New York: McGraw-Hill education. 